\title{
Učeče se skupnosti kot del kompetentnega sistema podpore za strokovne delavce: primer dveh slovenskih vrtcev
} Mateja Režek

\section{Ozadje in namen raziskave}

Tako med raziskovalci, praktiki kot tudi oblikovalci politik obstaja soglasje, da je kakovost pedagoške prakse v vrtcih v veliki meri odvisna od usposobljenosti strokovnih delavcev (Jensen in Rasmussen 2018). Vendar pa skrbi za kakovost vzgojno-izobraževalnega procesa ne smemo razumeti kot odgovornost zgolj posameznega strokovnega delavca, temveč je treba v skrb za kakovost vključiti time na ravni posameznih organizacij, izvajalce usposabljanj za strokovne delavce, lokalne skupnosti in nevladne organizacije, pa tudi nacionalne sisteme upravljanja, ki zagotavljajo pogoje za razvoj strokovnega kadra (Peeters et al. 2016). Govorimo torej o oblikovanju kompetentnega sistema. Ta obsega dimenzije znanj, praks in vrednot, ki so značilne za vse štiri ravni sistema: raven posameznika; raven institucije in timov znotraj te institucije, v kateri je posameznik zaposlen; raven medinstitucionalnega povezovanja ter raven upravljanja (Urban et.al. 2012). V okviru Centra za kakovost v vzgoji in izobraževanju Korak za korakom (v nadaljevanju Center) skrbimo za oblikovanje kompetentnega sistema na ravni Mreže za spreminjanje kakovosti Korak za korakom (v nadaljevanju Mreža), ', (Vonta 2011), ki jo lahko razumemo kot celosten sistem kontinuirane podpore za izboljševanje kakovosti vzgojno-izobraževalnega

1 Več o Mreži za spreminjanje kakovosti Korak za korakom https://www.korakzakorakom.si/katalog. 
procesa. $Z$ določenimi dejavnostmi v Mreži naslavljamo vodstvene delavce, saj so ključni pri oblikovanju vizije vzgojno-izobraževalnega zavoda, pri navduševanju, spodbujanju kot tudi pri zagotavljanju strukturnih pogojev za kakovosten vzgojno-izobraževalni proces. S posameznimi dejavnostmi pa neposredno krepimo strokovne delavce in jih opogumljamo za refleksijo lastne prakse in uvajanje sprememb vanjo. Na nivoju vrtca spodbujamo oblikovanje in delovanje profesionalnih učečih se skupnosti, ki jih vodi koordinator, in v katere se vključujejo tako strokovni kot tudi vodstveni delavci. Profesionalno učečo se skupnost lahko definiramo kot skupino strokovnih delavcev, ki se redno in kontinuirano sestaja $\mathrm{z}$ namenom refleksije lastne prakse, pridobivanja novih informacij, vključevanja $\mathrm{v}$ profesionalne razprave in poglabljanja specifičnih vsebin. Njihov cilj je izboljšati lastno pedagoško prakso in otrokovo dobro počutje (Cochran - Smith in Lytle 2002). Srečanja učečih se skupnosti potekajo po vnaprej določeni strukturi, ki članom omogoča priložnosti za povezovanje, refleksijo lastne prakse, oblikovanje skupnega razumevanja kakovosti znotraj izbranega vsebinskega področja ${ }^{2}$ in načrtovanje sprememb v okviru lastne prakse (Brajković, 2019).

\section{Projekt VALUE}

Profesionalne učeče se skupnosti smo v dveh slovenskih vrtcih poglobljeno raziskovali v okviru evropskega projekta VALUE - Pripoznavanje različnosti strokovnega osebja v vrtcu (2018-2020).

V projektu VALUE smo se osredotočali na krepitev sodelovanja med vsemi strokovnimi delavci, posebno pozornost pa smo namenili pomočnikom vzgojiteljem, pripoznavanju njihove vloge pri zagotavljanju kakovosti vzgojno-izobraževalnega procesa, krepitvi njihove profesionalne vloge in

2 Vsebinski okvir delovanja v Mreži predstavljajo ISSA pedagoška področja kakovosti. Ta so bila razvita na nivoju Mednarodnega združenja Korak za korakom (International Step by Step Association), opisujejo pa kakovostno, na otroka usmerjeno vzgojno-izobraževalno prakso, ki temelji na sodobnih spoznanjih raziskav o otrokovem razvoju, na teorijah učenja in nevroznanosti. Praksa, ki je usmerjena na otroka, je v tem dokumentu opisana skozi sedem pedagoških področij kakovosti, ki jih strokovni delavec uresničuje pri svojem delu. Ta področja so: Interakcije; Družina in skupnost; Inkluzija, različnost in demokratične vrednote; Spremljanje, načrtovanje in ocenjevanje; Strategije poučevanja; Učno okolje in Profesionalni razvoj. V praksi to pomeni, da si vrtec oz. osnovna šola, vključena $v$ Mrežo, v skladu $z$ lastnimi potrebami izbere pedagoško področje, ki ga $\mathrm{v}$ šolskem letu poglabljajo. Z izbranega področja vnašajo strokovni delavci v svojo prakso spremembe, jih reflektirajo, dodajajo nova spoznanja in informacije ter si nato na podlagi refleksije zastavijo nove cilje, ki ponovno služijo kot izhodišče za razmislek o svojem delu. 
identitete. Sodelovalne prakse smo krepili z namenom boljšega naslavljanja potreb otrok, družin in skupnosti. Pilotni projekt je po načelih akcijskega raziskovanja pod koordinatorstvom raziskovalk Pedagoškega inštituta (v nadaljevanju PI), Centra za kakovost v vzgoji in izobraževanju Korak za korakom, potekal od junija 2018 do oktobra 2019. V obeh vrtcih je bil v kontekstu oblikovanja podpornega sistema cilj oblikovanje učečih se skupnosti, vsebinski cilji pa so bili v obeh vrtcih različni, saj so izhajali iz vsebinskega področja, ki si ga je vsak vrtec izbral glede na lastne potrebe (Režek et.al. 2020). Oba vrtca sta že pred vključitvijo v projekt v okviru Mreže razvijala profesionalne učeče se skupnosti (USS), vendar sta $\mathrm{z}$ vključenostjo $\mathrm{v}$ projekt dobila priložnost za poglobljeno in individualizirano podporo vodjem učečih se skupnosti ter poglobljen razmislek o pomenu oblikovanja podpornega sistema za vse strokovne delavce.

\section{Opis intervencije}

Vrtca sta bila izbrana na podlagi motivacijskih pisem, $\mathrm{v}$ katerih so vodstvo in strokovni delavci opredelili motiv za sodelovanje ter izrazili pripravljenost za spreminjanje lastne prakse. V obeh vrtcih so bili v projekt vključeni vsi strokovni delavci.

\section{Prvo okolje}

Prvi vrtec je organizacijsko del osnovne šole. Leži v ruralnem naselju, 70 $\mathrm{km}$ vzhodno od Ljubljane. Deluje na treh lokacijah in vključuje 171 otrok in 24 zaposlenih, od katerih je 12 vzgojiteljic in 11 pomočnic vzgojiteljic ter en spremljevalec otroka s posebnimi potrebami. V vrtcu so se v zadnjih petih letih soočali s številnimi spremembami strokovnega in vodstvenega kadra, kar je vodilo do postopno slabše povezanosti med strokovnimi delavci, do pomanjkanja motivacije za profesionalni razvoj in šibkejše kulture učenja na nivoju vrtca. $V$ projektu so videli priložnost, da $\mathrm{z}$ novim, motiviranim vodstvom $\mathrm{v}$ vrtcu ponovno oblikujejo varno podporno okolje za refleksijo vzgojno-izobraževalne prakse, prostor za medsebojno učenje, povezovanje med strokovnimi delavci in s tem posledično vplivajo tudi na dvig kakovosti pedagoške prakse.

V zadnjih letih v vrtcu ugotavljajo, da se struktura prebivalstva v okolici spreminja. Priseljuje se vedno več družin, katerih materni jezik ni slovenščina, zaznavajo pa tudi povečano število otrok s posebnimi potrebami. Zaradi tega so si na nivoju vrtca za vsebino raziskovanja lastne prakse 
izbrali ISSA pedagoško področje Inkluzija, različnost, demokratične vrednote, ki naslavlja kompetence strokovnih delavcev na tem področju.

Na nivoju vrtca so oblikovali eno USS, ki so jo vodile tri vodje, od katerih je bila ena vodstvena delavka (pomočnica ravnateljice za vrtec). Med samo izvedbo srečanj USS so vodje skupino delile v manjše skupine, kar je omogočalo poglobljeno diskusijo, povezovanje in refleksijo prakse. Pri nadaljnji delitvi so bile vodje posebej pozorne na sestavo manjših skupin, in sicer na razmerje med vzgojiteljicami in pomočnicami vzgojiteljic ter na to, da tandemi oddelkov v manjših skupinah niso bili skupaj. Ta razmislek je bil pomemben zaradi razmerij moči med vzgojiteljicami in pomočnicami vzgojiteljic (Peeters 2016) ter zaradi prevzemanja pričakovanih in ustaljenih vlog v skupini (vodstvo je opozorilo, da bodo vzgojiteljice v primeru, da bodo v skupini skupaj s pomočnico vzgojiteljice iz svojega oddelka prevzemale bolj aktivno vlogo oz. se bodo tudi pomočnice pogosteje postavile $\mathrm{v}$ bolj pasiven položaj).

\section{Drugo okolje}

Drugi vrtec je organizacijsko samostojen in leži nekaj kilometrov jugovzhodno od Ljubljane. Vrtec deluje na devetih lokacijah, vključuje 720 otrok in zaposluje 89 strokovnih delavk, od katerih jih je več kot polovica (50) pomočnic vzgojiteljic. Zaposlujejo še logopedinjo, dve specialni pedagoginji in spremljevalca gibalno oviranemu otroku. Skrb za profesionalni razvoj vseh strokovnih delavcev je del vizije vrtca in eden osrednjih strateških ciljev. V projektu VALUE so videli priložnost za dodatno zunanjo podporo pri doseganju zastavljenega strateškega cilja. Kot prednostno nalogo so si v vrtcu v okviru letnega delovnega načrta zastavili krepitev ustvarjalnosti, področju pa so kot podporo pri refleksiji prakse s procesnega vidika pridružili še vseh sedem ISSA pedagoških področij kakovosti.

V USS so preoblikovali obstoječe strokovne aktive. Teh je bilo enajst, vsak pa je vključeval osem oz. devet strokovnih delavk. USS so bile zaradi številčnosti kadra in posledično zahtevnosti izvedbene logistike homogene (samo vzgojiteljice oz. pomočnice vzgojiteljic). Kljub temu so na pobudo strokovnih delavk izvedli dve »mešani« USS, kar je bil svojevrsten organizacijski zalogaj. Vodstvene delavke (ravnateljica, pomočnici ravnateljice, svetovalni delavki) so oblikovale svetovalno skupino, katere naloga je bila podpora vodjem USS. Pred vsako izvedbo USS so jim bile na voljo za skupno načrtovanje, iskanje dodatnih virov ipd. 


\section{Vloga zunanje podpore}

V obeh okoljih je bila vloga raziskovalk Centra podpora vodjem USS, s katerimi so se redno mesečno srečevale. $\mathrm{V}$ prvem vrtcu so se $s$ tremi vodji sestale sedemkrat, $\mathrm{v}$ drugem + pa $\mathrm{z}$ enajstimi vodji in svetovalno skupino desetkrat. Vsebina srečanj je bila refleksija njihove prakse vodenja USS, struktura teh podpornih srečanj pa je sledila siceršnji strukturi USS, tako da so raziskovalke modelirale izvedbo takih srečanj. Raziskovalke so omogočale povezovanje med vodji USS, refleksijo njihove prakse vodenja (diskusija o izzivih, dobrih praksah, ipd.), oblikovanje skupnega razumevanja kakovosti vodenja (na podlagi pripravljenih gradiv) ter vnašanje sprememb $\mathrm{v}$ prakso (z oblikovanjem akcijskih načrtov).

$\mathrm{V}$ celotnem procesu je bil velik poudarek namenjen formativnemu spremljanju lastnega profesionalnega razvoja strokovnih delavk, ki so v ta namen oblikovale individualen portfolio profesionalnega razvoja. Strokovne delavke so dokumentirale spremembe na področju razumevanja izbranih vsebinskih področij, vodje učečih se skupnosti pa spremembe na področju vodstvenih kompetenc. Učinke smo spremljali tudi prek skupinskega poglobljenega intervjuja.

\section{Raziskovalna metoda}

\section{Udeleženci}

$\mathrm{V}$ skupinskem poglobljenem intervjuju je sodelovalo 23 strokovnih in vodstvenih delavk obeh vrtcev, ki so sodelovala $\mathrm{v}$ projektu. Vključene so bile vodje USS ( 3 vzgojiteljice, 3 pomočnice vzgojiteljic, 1 pomočnica ravnatelja) ter člani USS (7 vzgojiteljic, 7 pomočnic vzgojiteljic) . Z ravnateljicama (2) je bil izveden polstrukturiran intervju.

\section{Pripomočki in postopek}

$\mathrm{Z}$ vodji in članicami USS smo izvedli skupinski poglobljeni intervju, $\mathrm{z}$ vodstvenimi delavkami pa polstrukturiran intervju.

Skupinske poglobljene intervjuje smo opravljali v vsakem okolju posebej in ločeno z vsako skupino. Pri oblikovanju skupin za skupinski poglobljeni intervju smo sledili načinu dela v USS v posameznem okolju. Tako je bil v prvem vrtcu intervju s člani USS izveden $\mathrm{v}$ mešani skupini (vzgojiteljice in pomočnice vzgojiteljic skupaj), v drugem okolju pa je bil izveden $\mathrm{v}$ dveh ločenih skupinah, in sicer posebej $\mathrm{z}$ vzgojiteljicami in posebej 
s pomočnicami vzgojiteljic. $Z$ vodji USS je bil skupinski poglobljeni intervju v obeh okoljih izveden v mešani skupini.

Vprašanja so bila oblikovana na podlagi vodil, (Jensen et. al. 2020), ki raziskujejo jedrne koncepte oblikovanja skupne profesionalne poti strokovnih delavcev, razvite za potrebe projekta VALUE. Vprašanja so bila razdeljena v tri (člani USS) oz. štiri (vodje USS) vsebinske sklope:

i) Vprašanja, osredinjena na jedrne koncepte, kjer nas je zanimalo predvsem dojemanje sprememb $\mathrm{v}$ profesionalni identiteti vzgojiteljic in pomočnic vzgojiteljic (kako razumejo svojo vlogo v oddel$\mathrm{ku}$; kako kompetentne se čutijo za delo z otroki, starši in sodelavci; kako poteka proces sprejemanja odločitev na nivoju oddelka) ter celostnega pristopa skrbi (razumevanje prepletenosti rutin, nege in učnih dejavnosti; deljenje nalog med obema strokovnima delavkama).

ii) Vprašanja, osredinjena na vpliv skupne profesionalne poti na sodelovanje med vzgojiteljicami in pomočnicami vzgojiteljic, kjer nas je zanimalo predvsem, kakšne spremembe so bile zaznane na nivoju neposrednega dela $v$ oddelku ter kakšne spremembe so zaznali starši.

iii) Vprašanja, osredinjena na zaznavo ključnih pogojev, ki vplivajo na uspešno delovanje USS.

iv) Vprašanja, osredinjena na zaznavo sprememb ključnih kompetenc vodij USS.

Podobno so bila v tri sklope razdeljena vprašanja za vodstvene delavce:

i) Vprašanja, osredinjena na zaznavanje sprememb na nivoju kolektiva, kjer nas je zanimal predvsem odnosni vidik sprememb.

ii) Vprašanja, osredinjena na zaznavanje sprememb na nivoju neposredne prakse, kjer so nas zanimali predvsem zaznani učinki na nivoju neposrednega dela $\mathrm{z}$ otroki in starši.

iii) Vprašanja, osredinjena na nadaljnje načrtovanje skupne poti profesionalnega razvoja za vse strokovne delavce, kjer nas je zanimalo predvsem, kako zagotoviti vzdržnost doseženih sprememb. 


\section{Učinki}

Največji učinki so bili zaznani na področju sodelovanja med strokovnimi delavkami. Strokovne in vodstvene delavke so poročale o:

- večji medsebojni povezanosti;

»Vsak načrt sva z vzgojiteljico oblikovali skupaj, skupaj sva ga tudi evalvirali. Prej nismo delali na tak način.« (pomočnica vzgojiteljice)

»Občutek, da se je zgodila večja povezanost, sodelovanje, medsebojno zaupanje, povezovanje; enakovrednost strokovnih delavk; da so se tudi začele rušiti posamezne osebne bariere, da so si upale povedati, se začele poslušati, bolj upoštevati druga drugo.«(ravnateljica vrtca)

- izboljšani komunikaciji na ravni strokovnih delavk, več medsebojnega učenja;

"Zelo dobro se mi zdi, da sva obe iz tandema sodelovali na srečanju iste učeče se skupnosti. Tako sva se lahko še kasneje pogovarjali o vsebinah, o katerih smo govorili na srečanju, in skupaj razmišljali o rešitvah, ki so najboljše za najino skupino. To je res fino, da smo vsi vključeni v učečo se skupnost, ker lahko še kasneje nadaljujemo z diskusijami, ki smo jih začeli na srečanju.« (pomočnica vzgojiteljice)

- večjemu zavedanju pomena kontinuirane podpore pri profesionalnem razvoju;

»Veliko sem naredila na sebi, na svoji praksi. Najbolj mi je pri tem pomagalo pisanje refleksij.« (pomočnica vzgojiteljice)

- o spremembah praks v kontekstu vsebin, ki so jih na nivoju vrtca poglabljali;

„Če ne bi tako poglobljeno razmišljale o kreativnosti in tako načrtno opazovale otrok ter hkrati oblikovale načrtov sprememb prakse, otrokom ne bi ponudile takšnih priložnosti za raziskovanje, kot smo jih zdaj.« (vzgojiteljica)

- o potrditvi svojega dela s strani kolegov. 
Zaznani so bili tudi učinki na ravni vodstva, pri čemer so vodstvene delavke poročale o večjem zavedanju pomena podpore na ravni vrtca.

»Tak način dela bomo uporabljali tudi v prihodnje. Razvojna skupina vodij učeče se skupnosti bo delovala kot podporna točka za delo učeče se skupnosti na ravni vrtca.« (ravnateljica)

\section{Zaključek}

V obeh okoljih sta bili USS pripoznani kot učinkoviti strategiji za povezovanje strokovnih delavcev in za spreminjanje prakse. Vodje USS so poročale, da je bila zunanja podpora raziskovalk Centra ključna za kakovostno USS. Med drugimi ključnimi pogoji za uspešno delovanje USS so bili prepoznani še motivirano vodstvo $\mathrm{z}$ vizijo profesionalnega razvoja strokovnih delavcev, ki jih vključuje v procese odločanja; dobro pripravljene vodje USS in motivirani strokovni delavci; jasna delitev vlog in opredeljene odgovornosti vodij in članov USS; čas in prostor izvedbe srečanj ter pozitivno vzdušje oz. varno učno okolje.

V obeh okoljih je bilo ključnega pomena, da so bili od samega začetka v proces vključeni vsi strokovni delavci, da so imeli možnost soodločati pri vsebini, ter da so na srečanjih USS izhajali iz lastne prakse.

\section{Literatura}

Brajković, Sanja. 2019. Profesionalne učeče se skupnosti v vrtcih in osnovnih šolah. Ljubljana: Pedagoški inštitut.

Cochran-Smith, Marilyn, Lytle, Susan L. 2002. Teacher Learning Communities - Teacher Learning and the New Professional Development, Community, Teacher Learning Communities. http://education.sta- teuniversity. com/pages/2483/Teacher-Learning-Communities.html

Jensen, Bente, Hulpia, Hester, Režek, Mateja, in Sousa, Joana. 2020. Supporting the collaboration between ECEC core and assisting practitioners. Endline report of the VALUE project in 4 countries (BE, DK, PT, SL). Copenhagen: Aarhus University. Pridobljeno s: https://www.value-ecec.eu

Jensen, Peter in Rasmussen, Astrid W. 2018. Professional development and its impact on children in early childhood education and care: A meta-analysis based on European studies. Scandinavian Journal of Educational Research. 63 (6): 935-950.

Peeters, Jan, De Kimpe, Chris in Brandt, Steven. 2016. The competent ECEC system in the city of Ghent: A long-term investment in continuous profe- 
ssional development. V Pathways to Professional Early Childhood Education, 57-71, ur. Michel Vandenbroeck, Mathias Urban in Jan Peeters, New York: Routledge.

Režek, Mateja, Jager, Jerneja in Mervic, Tina. 2020. Supporting the collaboration between ECEC core and assisting practitioners. Experiences of professional learning communities in two Slovenian pilot kindergartens. Ljubljana: Educational research institute. Pridobljeno s: https://www.value-ecec.eu/wp-content/uploads/2020/11/Country-Report_single-page_ SL.pdf

Tankersley, D., Brajković, S., Handžar, S., Rimkiene, R., Sabaliauskiene, R., Trikić, Z. in Vonta, T. (2013). Od teorije k praksi. Vodnik po pedagoških področjih kakovosti ISSA. Ljubljana: Pedagoški inštitut.

Urban, Mathias, Vandenbroeck, Michel, Lazzari, Arianna, van Laere, Katrien in Peeters, Jan. 2012. Competence Requirements in Early Childhood and Care. Final Report. London, Ghent: University of East London, Cass School of Education; University of Ghent, Department for Social Welfare Studies. Pridobljeno s: https://files.eric.ed.gov/fulltext/ED534599.pdf.

Vonta, Tatjana. 2011. Vloga mrežnega povezovanja v profesionalnem razvoju vzgojitelja. V: Vonta (ur.), Ševkušič (ur.): Izzivi in usmeritve profesionalnega razvoja učiteljev = Izazovi i usmerenja profesionalnog razvoja učitelja. Ljubljana: Pedagoški inštitut. 